\title{
Discrimination of Arid Vegetation with Airborne Multispectral Scanner Hyperspectral Imagery
}

\author{
Megan Lewis, Vittoria Jooste, and Aurelio A. de Gasparis
}

\begin{abstract}
Hyperspectral imagery from the airborne multispectral scanner was evaluated for discrimination and mapping of vegetation components in a semi-arid rangeland environment in Southern Australia. Automated unmixing of two image strips with 5-m resolution revealed several vegetation endmembers in the visible, near infrared (near-IR), and short-wave infrared portions of the imagery. Identity of the endmembers was determined through examination of their short-wave infrared and full-wavelength spectra, and their mapped distributions and correlation with percent cover of vegetation species were measured in sample plots. In addition, to assist interpretation of the image signatures, short-wave infrared reflectance spectra for the dominant vegetation components at the study site were collected with a portable infrared mineral analyzer (PIMA) spectrometer.

Endmembers separately mapped included Eucalyptus and other trees such as sugarwood, understorey chenopod shrubs, dry plant litter, and soil surface cryptogamic crust. Several endmembers were significantly positively correlated with field measurements of plant cover. Most of the tree canopy endmembers showed broad cellulose-lignin absorption features in the short-wave infrared (SWIR), and narrower absorptions caused by plant waxes and oils. The field spectra confirmed that the sclerophyll and xerophytic plants show identifiable cellulose, lignin, and plant wax absorption features, even when live and actively photosynthesising. This spectral expression of biochemical constituents in live plants points to the benefit of using the whole spectral range from visible to short-wave infrared in vegetation studies.
\end{abstract}

Index Terms-Hyperspectral imagery, mixture analysis, semi-arid vegetation, spectral features.

\section{INTRODUCTION}

$\mathbf{E}$ VEN IN arid regions, vegetation can form a considerable proportion of ground cover and contribute significantly to the scene reflectance recorded by imaging sensors. Understanding the nature and extent of the vegetation spectral contribution is important, not only for ecological applications where the vegetation is of primary interest, but also for soil and geological studies where the vegetation may confound interpretation. Over two decades of research with multispectral imagery has demonstrated its strength in discriminating and mapping physical vegetation variables (biomass, leaf area index, cover) and in monitoring vegetation condition (e.g., greenness) has been demonstrated, but discriminating vari-

Manuscript received October 20, 2000; revised March 13, 2000

M. Lewis is with the Department of Soil and Water, Adelaide University, Glen Osmond, South Australia 5064, Australia (e-mail: megan.lewis@adelaide.edu.au).

V. Jooste is with the Remote Sensing Section, Geoscience Centre, De Beers Consolidated Mines Ltd., Southdale 2135, South Africa.

A. A. de Gasparis is with the HyVista Corporation, Norwood 2117, South Africa.

Publisher Item Identifier S 0196-2892(01)05504-8. ations in vegetation composition has proven to be difficult. The existing multispectral sensors are inherently limited for discrimination of different species and variations in vegetation composition because of their broad bandwidths, the limited number of spectral bands, and their moderate to coarse spatial resolutions.

Hyperspectral imagery, however, offers considerable potential for discrimination of Earth surface materials because of its high spectral resolution, and when acquired from aircraft, its associated high spatial resolution. When applied to vegetation studies, these properties allow greater discrimination between different species and vegetation states than has been possible from imagery in the past. Because the fine resolution spectra of imaging spectrometers show the wavelength-specific absorptions and scattering caused by molecular bonds and cell structures, it is possible to identify differing quantities of plant compounds such as chlorophyll, lignin, cellulose, and silica, as well as leaf surface coatings and structures [1]-[7]. This offers the potential for assessment of plant physiological status and function, as well as discrimination of different plant types [8]-[12].

Airborne hyperspectral imagery has been used successfully for detection and mapping of minerals and soils, and discriminating crop types and condition, while most work in natural vegetation has been in North American grasslands, woodlands, and forests and chaparral [8], [9], [13]-[17]. To date, there has been little research with hyperspectral imagery in more arid vegetation types, yet the ability to detect and map variations in plant species composition and condition has great potential for monitoring this vast resource. Okin et al. [18] used spectral mixture analysis techniques with AVIRIS imagery in a North American arid environment, while Lewis [19] explored the potential for discrimination of southern Australian arid vegetation with the visible-near IR bands of CASI.

The most commonly used techniques for extraction and mapping of vegetation from hyperspectral imagery include variants of linear mixture analysis, which use a wide range of wavebands from the imagery [20], and wavelength-specific techniques such as narrow-band ratios and spectral absorption feature matching. In constrained linear mixture analysis, the number of spectral components or endmembers that can be extracted from a scene and related to reference spectra is inherently limited by the spectral dimensionality of the image data. Even for imagery comprising hundreds of channels, arid, and semi-arid scenes typically comprise green vegetation, nonphotosynthetic vegetation, shade and one or more soil components, although the relative abundances of these components may change throughout seasons and combine in different proportions to make up conventionally-recognized vegetation communities. Smith et al. [21] 
suggested that this group of endmembers, representing the fundamental scene components at a subpixel level, is intrinsic to arid and semi-arid scenes, and many subsequent studies with multispectral and hyperspectral imagery appear to have borne this out [8], [14], [22]-[27].

Wavelength-specific vegetation mapping techniques have utilized spectral features associated with chlorophyll absorption, particularly the "red edge" of the strong absorption feature at $0.68 \mu \mathrm{m}$ [4], [28]-[32], leaf water absorption bands at $0.95 \mu \mathrm{m}$ and $1.15 \mu \mathrm{m}$ [12], [33]-[35] starch absorption at $1.55 \mu \mathrm{m}$ [36], and lignin-cellulose absorptions at 2.09 and $2.27 \mu \mathrm{m} \mathrm{[3],} \mathrm{[7],}$ [33].

This paper presents results of a series of studies, set in a Southern Australian rangeland environment, which aimed to clarify the nature of semi-arid vegetation signatures in airborne hyperspectral imagery and to evaluate the potential of this imagery for discriminating and mapping variations in arid vegetation composition. The work placed particular emphasis on the short-wave infrared spectral region beyond $1.20 \mu \mathrm{m}$, since arid vegetation response in this region has been little studied, and this is the region where biochemical constituents may be detectable [1], [37], [38] and where vegetation reflectance most interferes with remote sensing of regolith and mineralogy.

\section{IMAGERY AND STUdY Site}

The study utilized imagery from the airborne multispectral scanner (AMS) operated by De Beers Consolidated Mines Ltd. The instrument is the precursor to the commercially operated HyMap, and is a 96-channel hyperspectral scanning imager operating from $0.53 \mu \mathrm{m}$ to $2.48 \mu \mathrm{m}$ with 96 bands of 15 to $25 \mathrm{~nm}$ and a swath of 512 pixels.

The work was conducted at two sites approximately $25 \mathrm{~km}$ east of Terowie on the south-eastern margin of the Australian pastoral zone in South Australia (Fig. 1). AMS imagery was acquired in July 1996 over Pandappa Conservation Park and several nearby pastoral properties. Two image strips were acquired, one of $20 \mathrm{~km}$ and the other $10 \mathrm{~km}$, both at $5 \mathrm{~m}$ resolution.

Both sites are semi-arid rangeland with low open woodlands and shrublands of chenopodiaceous species. Stands of multistemmed mallee Eucalypts are common in the area, while trees of black oak (Casuarina pauper) and sugarwood (Myoporum platycarpum) dominate the low open woodlands.

Rainfall in the region is approximately $225 \mathrm{~mm}$ p.a. and is quite unpredictable in magnitude and seasonality. At the time of imaging the landscape was relatively dry, with no significant rain having fallen for several months. The images included land that is grazed by cattle and sheep at different intensities and some areas in the conservation park that carry only native herbivores.

\section{METHODS}

\section{A. Image Analysis}

At the time of the study, the primary interest in AMS imagery was for detection of mineralogical anomalies. Consequently, the processing of the images employed rapid operational atmospheric correction and feature extraction methods designed for this purpose. A $\tan \theta$ correction was applied to the raw

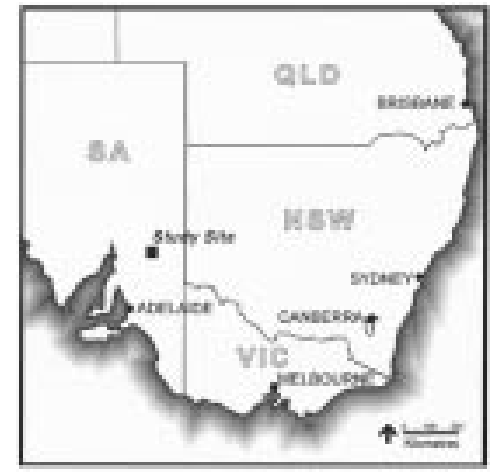

Fig. 1. Study site in the southeastern portion of the Australian arid zone.

image strips to correct for cross-track geometric distortion, accompanied by resampling of the original 512 pixel swath to 562 pixels. Subsequent processing was performed on these image strips, with georegistration to map coordinates only being applied to output endmember images. The images were segmented into visible-near IR (VNIR: 24 bands, 0.532-0.892 $\mu \mathrm{m}$ ), short-wave infrared 1 (SWIR1: 20 bands, 1.190-1.793 $\mu \mathrm{m}$ ) and short-wave infrared 2 (SWIR2: 22 bands, 1.190-1.793 $\mu \mathrm{m})$ subsets, removing the major water absorption regions. Atmospheric effects were compensated for using a modified log-residual process [39], effectively removing the scene-average spectrum. Automated spectral unmixing procedures were applied to each subset, producing 15 endmembers from each spectral region. This procedure identifies a set of "seed" endmember pixels, whose spectra, when combined, account for as much of the scene spectral variation as possible. The unmixing then produces images of relative abundance for each endmember [40]. These were scaled to highlight areas of high endmember abundance.

AMS image spectra were extracted for the endmember "seed" pixels, and also for the regions of high abundance in the output endmember images. The identity of the endmembers was determined through examination of these spectra, the spatial distribution of the endmembers, and comparison with field data.

\section{B. Field Data}

The endmembers were interpreted through field reconnaissance of both sites. Several cross-fence vegetation discontinuities and contrasts, brought about by different grazing and management regimes, particularly helped this interpretation. In addition, quantitative data on percentage cover of vegetation, soil, litter and lichen was collected for $4450 \times 50$ and $100 \times 100 \mathrm{~m}$ plots throughout the images. There were 33 plots for the larger Pine Creek image and 11 for the Pandappa image, all located with differential GPS.

A wheelpoint apparatus was used to estimate the ground cover composition within the plots. The wheelpoint and its variant step pointing is widely used in Australia and South Africa for rapid, quantitative estimation of soils and vegetation cover in low, sparse rangeland vegetation, and has been used successfully to correlate ground composition with image variables in rangeland remote sensing studies [41], [42]. Approximately 1000 point records were collected along ten parallel $100 \mathrm{~m}$ transects within the plots. For each plot, the 
percentage cover of bare soil, ground covering plant litter, cryptogamic crust, trees and shrubs was calculated from the proportion of point "hits" on each component.

The endmember images were georegistered to the Australian map grid using points recorded in the field with a differential GPS. Blocks of pixels corresponding to the field sample sites were extracted from the images and mean abundance of the endmembers calculated within these. Statistical correlation was tested between endmember abundance and percentage cover of vegetation components measured in the field.

To assist interpretation of the AMS vegetation signatures in the SWIR region, reflectance spectra for the dominant vegetation components at the study site were collected with a portable infrared mineral analyzer (PIMA) portable spectrometer, operating over the range $1.30-2.50 \mu \mathrm{m}$. This spectral collection also included variations in plant age and condition. Fresh plant specimens were collected in the field, and sealed in plastic bags for no more than two hours before spectral measurement. For broad-leaved plants, such as the Eucalypts, several layers of leaves were used to directly cover the aperture of the PIMA instrument. The small twiggy or semi-succulent leaves of the undershrub plants were more difficult to measure, and in most cases the foliage was stripped from the plant and used to fill a glass petri dish that covered the PIMA aperture.

\section{RESULTS}

\section{A. Endmembers}

The endmembers from the automated unmixing of each of the AMS images are summarized in Table I. They include upper and lower-storey vegetation components, soils, outcropping rocks and their mineral constituents, topographic and vegetation shadow and a few endmembers that could not be identified, including those with little spatial coherence, interpreted as image noise. Examples of vegetation endmembers from both AMS images are shown in Figs. 2 and 3. Subsets of the larger image strips are shown to enhance detail of the vegetation patterns that have been mapped. The figures show endmembers interpreted as total vegetation cover, mallee Eucalyptus canopies, canopies of the arid woodland tree Myoporum platycarpum (sugarwood), chenopod shrubs, dry herbaceous plant litter, and soil-encrusting lichen.

The automated unmixing of the AMS images typically produced four to five vegetation endmembers in the VNIR region. These mapped different vegetation components, separately showing Eucalypts, sugarwoods, total plant cover including perennials and ephemerals, and the soil-encrusting lichens that were abundant in some areas. Sometimes the endmembers appeared to be subtle albedo variations associated with the same vegetation component, e.g., Eucalyptus canopies. Directional bias in their distributions suggested they were associated with the sunlit and shaded portions of the canopies.

The SWIR1 portion of the images yielded three to four endmembers that could be associated with vegetation components. These mapped Eucalypt canopies, other trees, and understorey shrubs. The SWIR2 portion of the images also produced at least two endmembers associated with vegetation. One of these mapped the trees and larger green shrubs in the Pandappa image, one a component of the chenopodiaceous understorey at
TABLE I

SUMMARY OF ENDMEMBERS DERIVED FROM AUTOMATED UNMIXING OF TWO AMS IMAGES

\begin{tabular}{|c|c|c|c|}
\hline \multirow[b]{2}{*}{$\begin{array}{c}\text { Wavelength } \\
\text { segments }\end{array}$} & \multirow[b]{2}{*}{ End-members } & \multicolumn{2}{|c|}{$\begin{array}{c}\text { Number of Image } \\
\text { End-members }\end{array}$} \\
\hline & & Pine Creek & Pandappa \\
\hline $\begin{array}{l}\text { VNIR } \\
0.532-0.892 \mu \mathrm{m}\end{array}$ & $\begin{array}{l}\text { Eucalypt canopies } \\
\text { All tree canopies } \\
\text { Sugarwood canopies } \\
\text { Total plant cover } \\
\text { Cryptogamic soil crust } \\
\text { Soils and minerals } \\
\text { Shadow } \\
\text { Unidentified or noise }\end{array}$ & $\begin{array}{l}3 \\
1 \\
6 \\
1 \\
2\end{array}$ & $\begin{array}{l}3 \\
1 \\
1 \\
1\end{array}$ \\
\hline $\begin{array}{l}\text { SWIR1 } \\
1.190-1.793 \mu \mathrm{m}\end{array}$ & $\begin{array}{l}\text { Eucalypt canopies } \\
\text { All tree canopies } \\
\text { Sugarwood canopies } \\
\text { Chenopod shrubs } \\
\text { Dry vegetation } \\
\text { Soils and minerals } \\
\text { Shadow } \\
\text { Unidentified or noise }\end{array}$ & $\begin{array}{l}6 \\
3 \\
3\end{array}$ & $\begin{array}{l}4 \\
1 \\
1 \\
1 \\
3 \\
4 \\
1\end{array}$ \\
\hline $\begin{array}{l}\text { SWIR2 } \\
1.190-1.793 \mu \mathrm{m}\end{array}$ & $\begin{array}{l}\text { Chenopod shrubs } \\
\text { Dry vegetation } \\
\text { Soils and minerals } \\
\text { Shadow } \\
\text { Unidentified or noise }\end{array}$ & $\begin{array}{c}1 \\
2 \\
10 \\
2\end{array}$ & $\begin{array}{c}1 \\
1 \\
10 \\
2 \\
1\end{array}$ \\
\hline
\end{tabular}

the Pine Creek site, while others appeared to be associated with the dry plant litter that is a significant ground cover component at both sites. They showed marked contrasts across property boundary fences, mapping variations in ground cover produced by differential stock grazing.

\section{B. AMS Vegetation Signatures}

Figs. 2 and 3 present the SWIR2 image spectra for selected endmembers, comparing the spectra of the "seed" pixels with mean spectra for high abundance regions. The figure also presents mean endmember spectra for the full range of AMS bands. The SWIR2 spectra alone were often difficult to interpret, but examination of the full-wavelength spectra helped confirm the identity of the endmembers. Because of the log-residual processing applied to the imagery, the image vegetation signatures could not be directly compared with true reflectance reference spectra. However, the relative position and depth of absorption features enabled recognition of vegetation signatures and comparison with known plant spectral absorption characteristics.

Most of the tree canopy endmembers showed the chlorophyll absorption and high NIR reflectance typical of photosynthetic vegetation, while in the SWIR displayed a broad cellulose-lignin absorption between 2.10 and $2.20 \mu \mathrm{m}$, and a narrower feature in the AMS band centred on $2.317 \mu \mathrm{m}$. Several also showed absorptions at $2.284 \mu \mathrm{m}$ and $2.40 \mu \mathrm{m}$. The $2.317 \mu \mathrm{m}$ and $2.40 \mu \mathrm{m}$ bands are near recorded absorptions for plant waxes, and the $2.28 \mu \mathrm{m}$ feature may correspond to one of the cellulose absorptions [37]. In most instances, the characteristic spectral features of the endmember pixels were also present in the mean endmember spectra, although often less pronounced. 


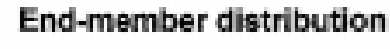

High abundince reglons ahown in colour
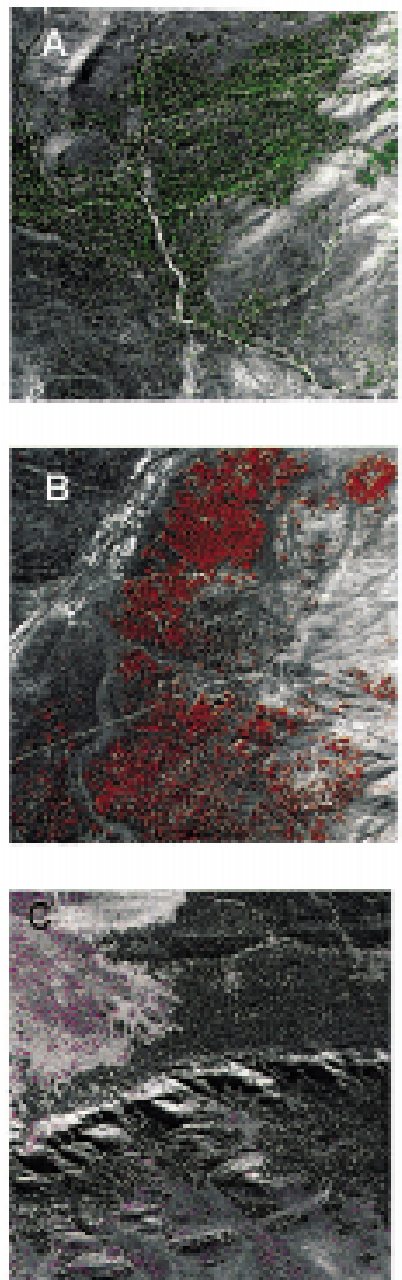

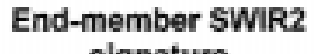
signature

Black - endinamber soed phek Red - resese sectrum fran high abundance rogions. spoctra stacked for clarty.
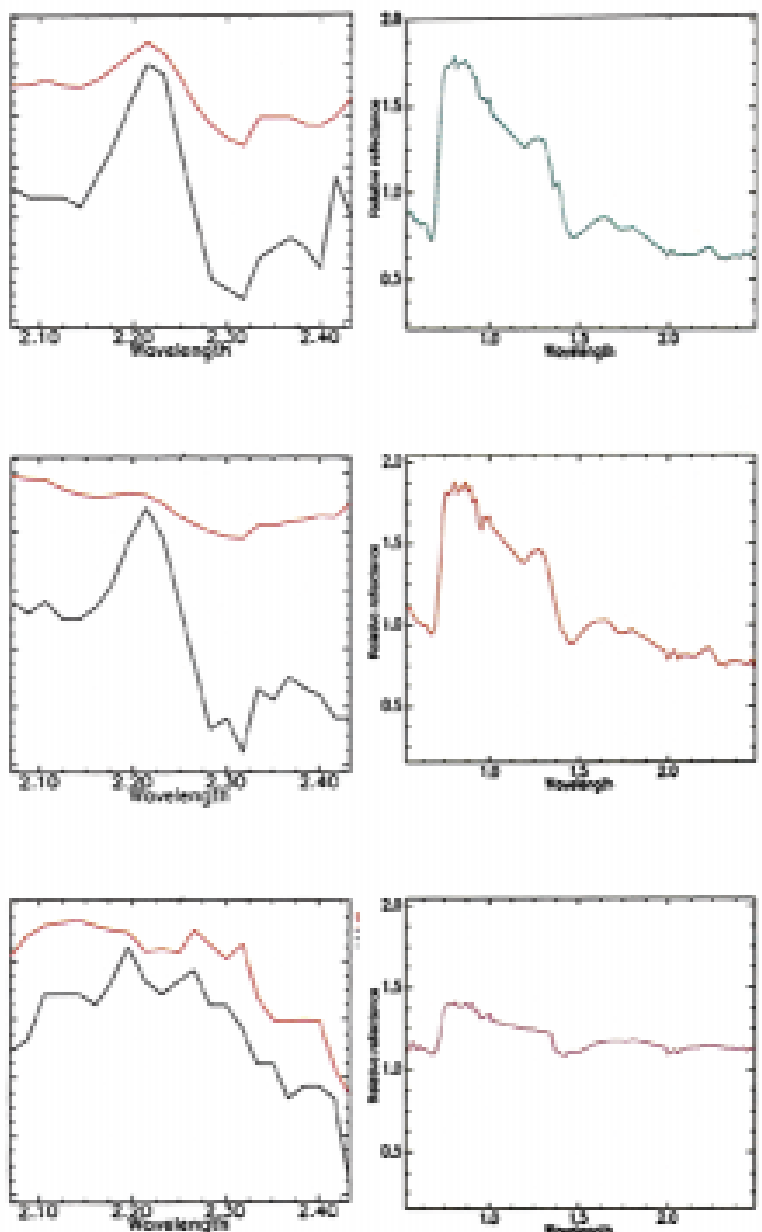

Mean end-member signature

Hob abundance rogibne, insgo conoctod uath intemal susrege relotive refectence

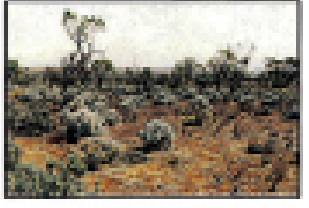

Total liwe plant cover War andmember $13 \mathrm{ks}$ Tobar kie plont ocver $R=0.57, p<0.001, \pi=33$
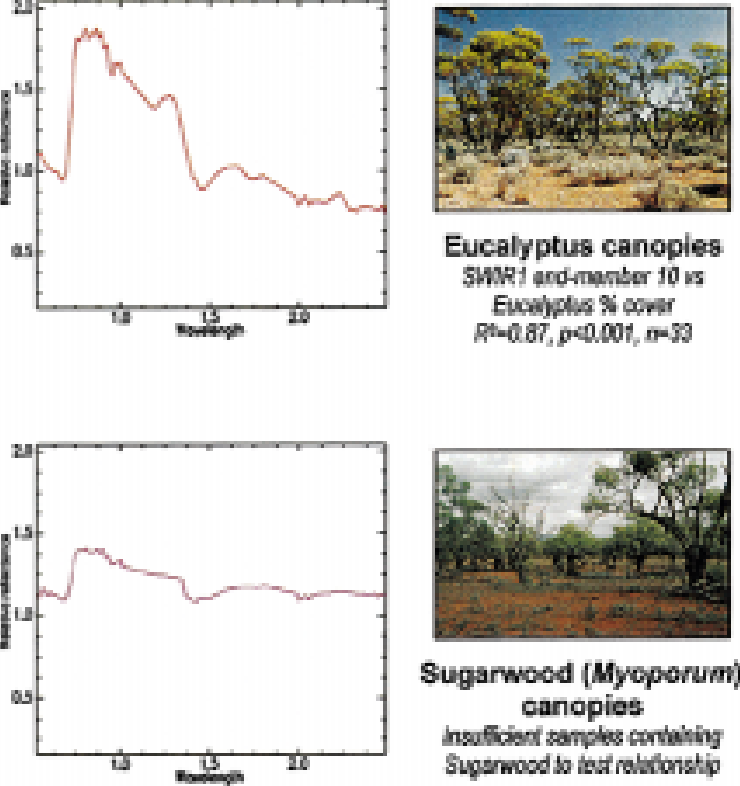

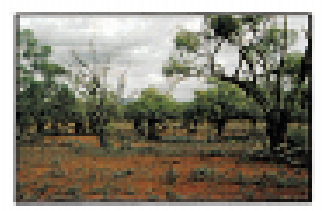

Sugarwood (Myoporum) canopios

insufficort samples contaiting Sugerwood to itst ratutonstip

Fig. 2. Examples of vegetation endmembers from automated unmixing of AMS imagery. A) Total live plant cover, B) Eucalyptus canopies, and C) Sugarwood (Myoporum platycarpum) canopies. Columns show for each endmember: endmember distribution, SWIR2 signatures of seed pixels and mean spectra for high endmember abundance regions, mean full-wavelength spectrum for high endmember abundance regions, and the corresponding vegetation component and correlation with field data.

Image signatures of the understorey vegetation, however, were more varied and less readily identifiable. Most of the spectra showed low "greenness" in the VNIR, and evidence of mixing with soil spectra in both VNIR and SWIR. In some instances, the "inversion" of the mean spectrum in the VNIR, an artefact of the log-residual processing, indicated that the endmember pixels carried less photosynthetic vegetation than the scene average. Some SWIR2 image spectra showed the broad cellulose-lignin absorption between 2.10 and $2.20 \mu \mathrm{m}$ common in the tree spectra, while several others showed a broad peak of reflectance from 2.10 to $2.20 \mu \mathrm{m}$, suggestive of vegetation with high water content.

\section{Correlation with Field Data}

Plant cover in most sample plots was less than 30\%. Significant statistical correlations were established between the abundance of several image endmembers and percentage cover of vegetation components as measured in the plots. Examples of the most significant of these correlations are listed in Table II, while Figs. 2 and 3 show the relationships for the endmembers that have been displayed. Significant positive linear relationships existed between several of the VNIR and SWIR1 endmembers and Eucalyptus canopy cover, and total plant cover. Several of the SWIR2 endmembers that were interpreted to show dry plant litter also had positive correlations with exposure of bare soil, indicating that the endmember was in fact mapping a mixture of the two ground cover components.

\section{PIMA Vegetation Signatures}

The plant spectra acquired with the PIMA spectrometer-assisted interpretation of features in the image vegetation signatures. Examples of these spectra, selected for comparison with 

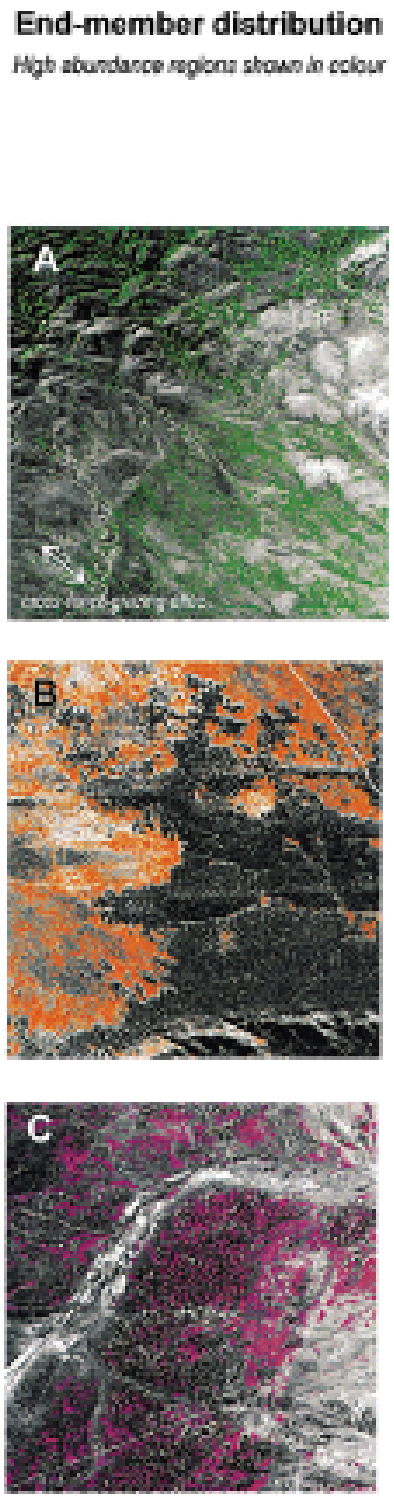

\section{End-member SWIR2} signature

Buck - sodinumber sced pinct Rad- meas sectrow horo ha atuntanct resiont.

Spoctra stuchad for dalats.
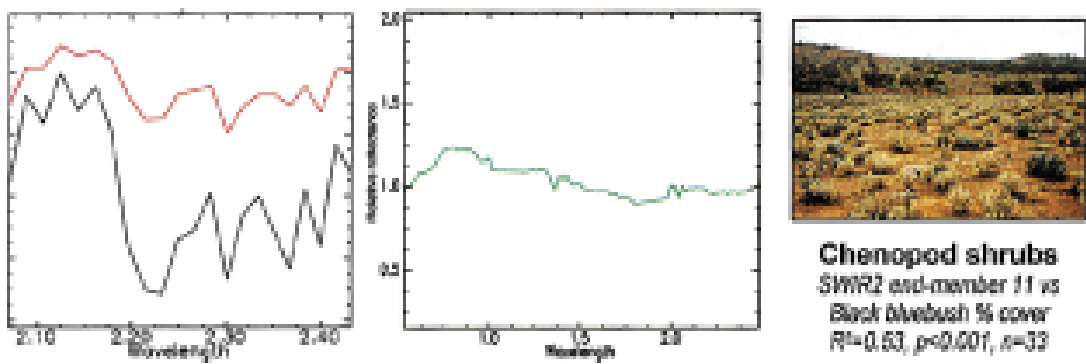

Chenopod shrubs

swi2 and-menuer 11 vs Buct Alubush \& coner Rto $0.53,000.001,8=3$ ?
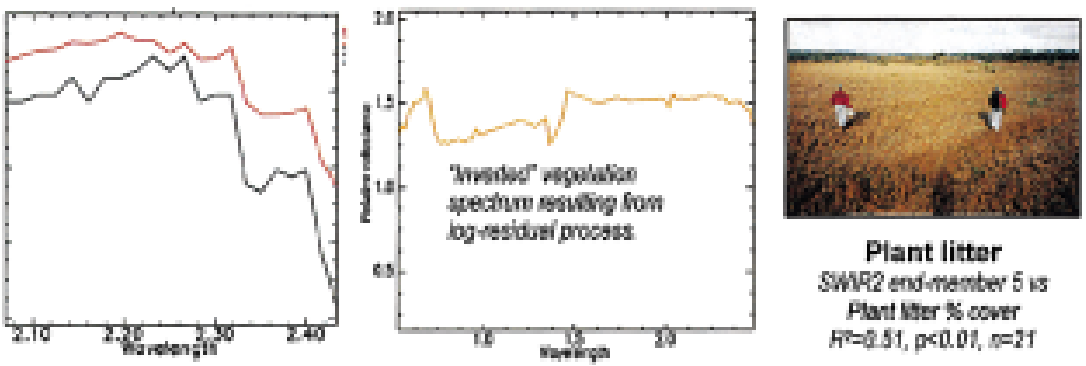

Plant litter

SWR2 end-manter 5 us Plant Lfer \$ oover Fin: $051, p<0.01, n=21$
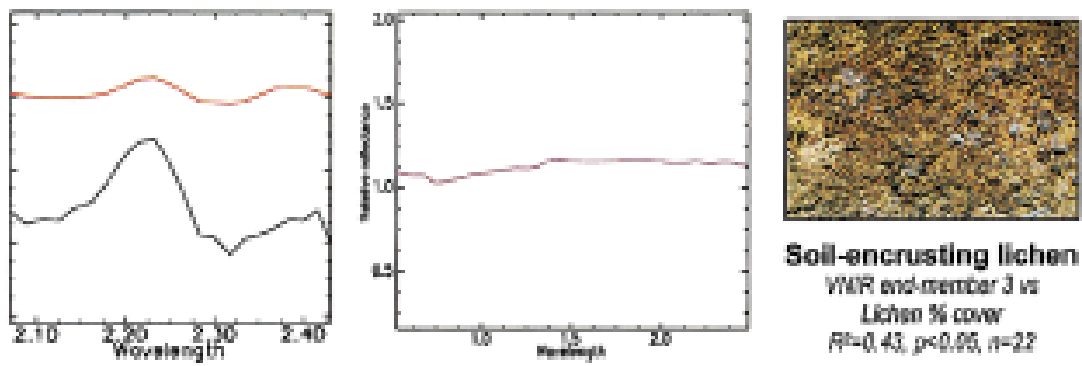

Fig. 3. Examples of vegetation endmembers from automated unmixing of AMS imagery. A) Chenopod shrubs, B) plant litter, and C) soil cryptogamic crust. Columns show for each endmember: endmember distribution, SWIR2 signatures of seed pixels and mean spectra for high endmember abundance regions, mean full-wavelength spectrum for high endmember abundance regions, and the corresponding vegetation component and correlation with field data.

TABLE II

CORRELATIONS BETWEEN IMAGE ENDMEMBERS AND FIELD VEGETATION COMPONENTS. SIGNIFICANCE LEVELS: ${ }^{*} p<0.05,{ }^{* *} p<0.01$, AND ${ }^{* * * *} p<0.001$

\begin{tabular}{llllc}
\hline \multicolumn{1}{c}{ Scene end-members } & \multicolumn{1}{c}{$\begin{array}{c}\text { Field cover component } \\
\text { \% cover }\end{array}$} & N & $\mathbf{R}^{2}$ & Significance \\
\hline VNIR end-member 2 & Eucalyptus canopy & 33 & 0.76 & $* * * *$ \\
VNIR end-member 6 & Total plant, litter \& lichen cover & 33 & 0.49 & $* * *$ \\
VNIR end-member 13 & Total live plant cover & 33 & 0.57 & $* * *$ \\
VNIR end-member 3 & Lichen cover & 22 & 0.43 & $*$ \\
SWIR1 end-member 10 & Eucalyptus canopy cover & 33 & 0.87 & $* * *$ \\
SWIR2 end-member 5 & Plant litter & 21 & 0.51 & $* *$ \\
SWIR2 end-member 11 & Black bluebush cover & 33 & 0.53 & $* * *$ \\
\hline
\end{tabular}

image endmembers, are shown in Fig. 4. Spectra of fresh foliage from the Eucalypts and other trees were dominated by strong water absorptions at $1.40 \mu \mathrm{m}$ and $1.90 \mu \mathrm{m}$, and a relatively broad, weak cellulose-lignin absorption at $1.70 \mu \mathrm{m}$. Al- though albedo beyond $1.90 \mu \mathrm{m}$ was low and strongly influenced by water absorption, broad absorptions around 2.10 and 2.30 $\mu \mathrm{m}$, and traces of narrow absorptions at $2.31 \mu \mathrm{m}$ and $2.36 \mu \mathrm{m}$ were still evident. As the foliage dried out, the near IR shoulder $(1.30-1.40 \mu \mathrm{m})$ collapsed and absorptions due to cellulose and lignin became more prominent at $1.70-1.80 \mu \mathrm{m}, 2.00-2.20 \mu \mathrm{m}$, and 2.26-2.38 $\mu \mathrm{m}$. Dry Eucalyptus leaves and Eucalyptus bark showed distinct absorptions at $1.73 \mu \mathrm{m}, 1.76 \mu \mathrm{m}, 2.31 \mu \mathrm{m}$ and $2.35 \mu \mathrm{m}$.

The chenopod shrub spectra varied considerably with plant condition. Leafy saltbush displayed a higher albedo than the tree foliage spectra, while bluebush shrubs had lower albedo with less contrast between the SWIR1 and SWIR2. Regardless of condition, the shrub spectra showed traces of broad cellulose and lignin absorptions and narrow features around $1.73 \mu \mathrm{m}$, $2.31 \mu \mathrm{m}$, and $2.35 \mu \mathrm{m}$. The herbaceous understorey plants, including grasses and onion weed, showed greatest variation in 

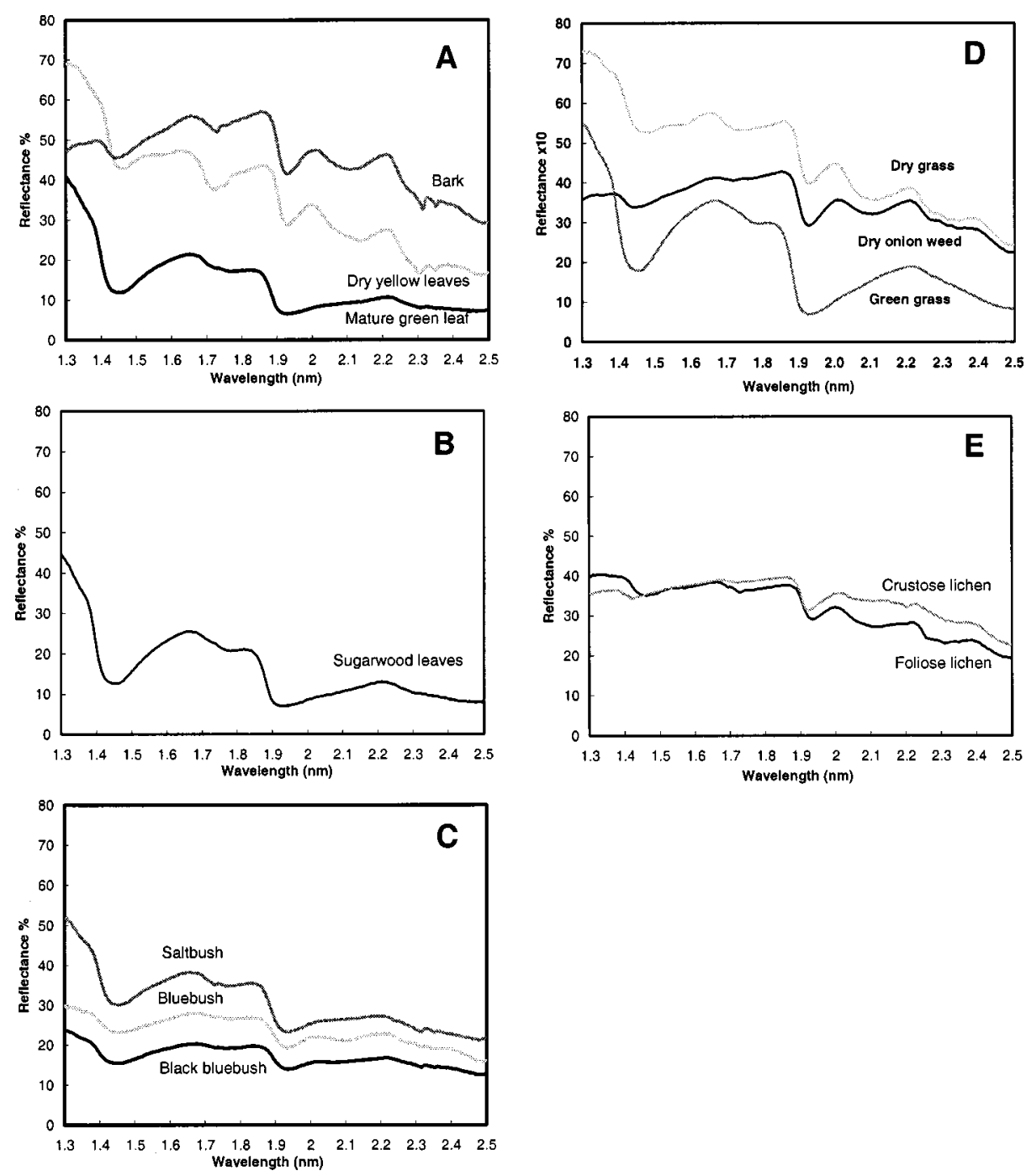

Fig. 4. Examples of PIMA spectra from arid plant species corresponding to AMS vegetation endmembers: A) fresh and dry Eucalyptus leaves and bark; B) sugarwood leaves; C) chenopod shrubs: saltbush, bluebush, and black bluebush, D) dry grass and onion weed, and E) crustose and foliose lichens on soil.

spectral response with plant condition. In the very green specimens, water absorptions dominated, but as the plants dried out, albedo increased, water absorption decreased, and absorption features at $1.70-1.80 \mu \mathrm{m}, 2.00-2.20 \mu \mathrm{m}$, and $2.26-2.38 \mu \mathrm{m} \mu \mathrm{m}$ became evident. Soil-encrusting lichens, which were dry at the time of sampling, also showed absorptions in the $1.70-1.80 \mu \mathrm{m}$ and $2.00-2.20 \mu \mathrm{m}$ regions.

\section{DISCUSSION AND CONCLUSIONS}

Several arid vegetation components were successfully mapped by the automated mixture analysis of AMS hyperspectral imagery. These corresponded to functional components of the vegetation (trees versus shrubs), to differences in species (Eucalyptus versus other tree species) and to different physiological states (green ground cover versus dry litter). The establishment of statistical relationships between endmember abundance and field measurements of plant cover is significant in that it helps confirm the identity of several of the endmembers but also further establishes that the endmembers correspond to real landscape components and are not merely abstractions from image processing.

All spectral regions of the imagery yielded vegetation endmembers, including the SWIR2. It has been generally presumed that most spectral information about vegetation can be derived from the VNIR and that water content masks most of the spectral features of live plant material in the SWIR [37], although there have been some successes in detection and mapping of live vegetation biochemistry using hyperspectral imagery [15], [36], [43], [44]. Most of these studies have focused on the spectral features associated with particular biochemical constituents, although Wessman et al. [9] used mixture analysis of the SWIR region of AVIRIS imagery to map the lignin component of vegetation. The SWIR PIMA spectra and the AMS vegetation endmember spectra examined in this study also demonstrate that spectral features related to biochemical constituents are detectable in live vegetation and may be mapped from airborne hyperspectral imagery.

Most of the tree and shrub PIMA spectra showed traces of cellulose and lignin absorption features, even though the specimens were fresh, photosynthetic, and in some cases 
quite succulent. This may be attributed to the architecture of the plants in some cases. For example, the saltbushes and bluebushes are woody shrubs with reduced leaf area and much thickening tissue, hence, the greater influence of structural materials on the spectra. The leaves of several species such as the Eucalypts, black oak, and bullock bush also display scleromorphic characteristics typical of many arid species: development of leaf thickening tissue as an adaptation to prevent tissue damage and wilting under moisture stress. Again, the increased proportion of thickening tissue is likely to contribute to foliar SWIR2 reflectance.

In addition to expression of broad cellulose-lignin absorptions, many of the live plant spectra showed specific, narrow absorptions near $1.73 \mu \mathrm{m}, 2.31 \mu \mathrm{m}$, and $2.35 \mu \mathrm{m}$. These features became more prominent in dry Eucalypt leaves and bark and were even present in dry grass spectra. These wavelengths are diagnostic of plant-based fats and oils [37], [38], [45], and 2.306 $\mu \mathrm{m}$ is used as a diagnostic absorption for spectroscopic determination of fats in cereal-based foods [46], [47]. Other wavelengths for detection of fats are 1.21, 1.39, 1.72, 1.76, and 2.34 $\mu \mathrm{m}[46]$ and $1.72,2.35$, and $2.35 \mu \mathrm{m}$ [47].

In the case of the Eucalyptus leaves, the high content of volatile aromatic oils suggests a cause for these spectral features. In the fresh leaves, the oil absorption is largely masked by water absorption but is still just detectable, whereas in the dry leaves that have lost their moisture but still retain the oil, the absorptions are far more prominent. However, the same features are evident in the fresh leaf spectra for many of the other trees and shrubs, species not particularly noted for high oil contents, suggesting that compounds other than Eucalyptus oil are involved. In these cases the absorption is likely to be caused by the waxy cuticle that covers the leaf surfaces. In most of the species examined in this study the cuticle is quite well developed, either as a thick smooth layer (Eucalypts, sugarwood) as a blanket of hairs (bullock bush, bluebushes) or bladders (saltbushes). The cuticle is composed of cutin, a waxy substance, and serves as an adaptation to reduce solar irradiation and moisture loss.

Some of these spectral features were also evident in the spectra for endmembers derived from the AMS imagery. For example, many of the tree canopy endmembers and some understorey endmembers showed absorptions near 2.10-2.20 $\mu \mathrm{m}$ and $2.31 \mu \mathrm{m}$ that correspond with features shown in the PIMA spectra. Other understorey endmembers showed a rounded peak of reflectance near $2.20 \mu \mathrm{m}$, more characteristic of the PIMA plant spectra with high moisture contents.

Comparison of the SWIR with VNIR portion of the endmember spectra, however, reveals interesting patterns. Many of the endmember spectra that show distinct SWIR2 absorption features also show the sharp VNIR red-edge characteristic of actively photosynthesising vegetation. In other words, although the plants are actively growing, moisture does not entirely mask the spectral expression of biochemistry in the SWIR region. Conversely several of the understorey spectra that show high moisture in the SWIR2 have the relatively "flat" VNIR spectra typical of low photosynthetic activity, senescing plants or low plant cover. These spectral patterns, although apparently anomalous, do accord with the field situation at the study site.
The understorey shrubs and herbs were relatively sparse, typically covering less than $15 \%$ of the ground, allowing significant mixing of soil and vegetation response at the pixel level. Several of the common ground covers, particularly the widespread onion weed, are quite herbaceous, and in their "green" state have spectra dominated by water, while the semi-succulent foliage of the chenopod shrubs displays subdued VNIR spectra and moisture-dominated SWIR.

These vegetation endmember spectra depart from those typically used in conventional linear mixture analysis of hyperspectral imagery. The vegetation in arid and semi-arid scenes, and even more mesic vegetation, is typically modeled as mixtures of green photosynthetic vegetation and dry nonphotosynthetic vegetation with shade and one or more soil components [20], [21]. The green spectral component is usually interpreted as ephemeral vegetation, while the dry signatures are usually associated with perennial vegetation or sometimes with dry grass (for example [14], [25]). However, the results presented here suggest that vegetation endmembers, corresponding to real vegetation components, may appear "green" in the VNIR and relatively "dry" in the SWIR, and vice versa. The automated unmixing procedure used in this study also provided a wider set of vegetation endmembers than is normally accommodated by conventional constrained linear mixture routines.

These findings need to be confirmed with follow-up studies that simultaneously measure VNIR and SWIR field spectra for the plants, preferably with a spectrometer spanning the $0.40-2.40 \mu \mathrm{m}$ range. This would build understanding of the relationship between VNIR and SWIR spectral behavior for semi-arid vegetation under a range of conditions. More confidence about the AMS spectral features and endmember identity could also be gained through the use of an atmospheric correction that calibrates the imagery more closely to true reflectance and enables a closer comparison between field and image spectra.

The spectral expression of biochemical constituents in live plants shown in this study points to the benefit of using the whole spectral range from visible to short-wave infrared in hyperspectral vegetation studies. The short-wave as well as visible-near IR regions can yield information about "green" and "dry" plant components that may be useful for vegetation characterization. Results of this study also emphasize the importance of understanding the spectral properties of the particular plants, environments, and conditions being imaged: assumptions about vegetation spectral properties derived from studies in more mesic environments may not be correct.

The study illustrates some of the potential for use of hyperspectral imagery to discriminate variation in arid vegetation; communities that typically have low percentages of cover and leaf area, high proportions of woody and dry tissue, and which may show little photosynthetic activity. Both green and dry vegetation can be discriminated from the soil background at less than $30 \%$ cover, and several functional components within the live vegetation can be identified. Such mapping can offer considerable benefits for ecological and land management applications such as habitat mapping, rangeland condition assessment, landscape pattern analysis, and monitoring shifts in vegetation composition. 


\section{ACKNOWLEDGMENT}

The authors would like to thank De Beers Consolidated Mines Ltd. and the Geophysical Services Department of Anglo American Corporation of South Africa Ltd., for the imagery for the study. They would also like to thank the Remote Sensing Section of the De Beers Geoscience Centre, Johannesburg, South Africa for the imagery and the postgraduate students from the Faculty of Agricultural and Natural Resource Sciences, The University of Adelaide, Adelaide, Australia, for collection of field data. Finally, they would like to thank Stockdale Prospecting Pty Ltd. for use of the PIMA spectrometer

\section{REFERENCES}

[1] C. A. Wessman, "Evaluation of canopy biochemistry," in Remote Sensing of Biosphere Function, R. J. Hobbs and H. A. Mooney, Eds. New York: Springer-Verlag, 1989, pp. 135-156.

[2] S. L. Ustin, C. A. Wessman, B. Curtiss, E. Kasischke, J. Way, and V. C. Vanderbilt, "Opportunities for using the EOS imaging spectrometers and synthetic aperture radar in ecological models," Ecology, vol. 72, pp. 1934-45, 1991.

[3] G. M. Smith and P. J. Curran, "Exploring the remote sensing of foliar biochemical concentrations with AVIRIS data," in Summaries 3rd Annu. JPL Airborne Geoscience Workshop, AVIRIS Workshop, vol. 1, Pasadena, CA, June 1-5, 1992, JPL Pub. 92-14 NASA/JPL, pp. 50-52.

[4] C. D. Elvidge, Z. Chen, and D. P. Groeneveld, "Detection of trace quantities of green vegetation in 1990 AVIRIS data," Remote Sens. Environ., vol. 44, pp. 271-79, 1993.

[5] F. Baret and S. Jacquemoud, "Modeling Canopy Spectral Properties to Retrieve Biophysical and Biochemical Characteristics," in Imaging Spectrometry - a Tool for Environmental Observations, J. Hill and J. Megier, Eds. Dordrecht, The Netherlands: Kluwer, 1994, pp. $145-167$

[6] C. A. Wessman, "Estimating Canopy Biochemistry Through Imaging Spectrometry," in Imaging Spectrometry — a Tool for Environmental Observations, J. Hill and J. Megier, Eds. Dordrecht, The Netherlands: Kluwer, 1994a, pp. 56-69.

[7] M. E. Martin and J. D. Aber, "Estimation of forest canopy lignin and nitrogen concentration and ecosystem processes by high spectral resolution remote sensing," Ecol. Applicat., pp. 7431-7443, 1997.

[8] D. E. Sabol, D. A. Roberts, J. B. Adams, and M. O. Smith, "Mapping and monitoring changes in vegetation communities of Jasper Ridge, CA, using spectral fractions derived from AVIRIS images," in Summaries 4th Annu. JPL Airborne Geoscience Workshop, AVIRIS Workshop, vol. 1, Pasadena, CA, Oct. 25-29, 1993, JPL Pub. 93-28, NASA/JPL, pp. $157-60$.

[9] C. A. Wessman, C. A. Bateson, B. Curtiss, and T. L. Benning, "A comparison of spectral mixture analysis and NDVI for ascertaining ecological variables," in Summaries 4th Annu. JPL Airborne Geoscience Workshop, AVIRIS Workshop, vol. 1, Pasadena, CA, Oct. 25-29, 1993, JPL Pub. 93-28, NASA/JPL, pp. 193-96.

[10] R. H. Yuhas, J. W. Boardman, and A. F. H. Goetz, "Determination of semi-arid landscape endmembers and seasonal trends using convex geometry spectral unmixing techniques," in Summaries 4th Annu. JPL Airborne Geoscience Workshop, AVIRIS Workshop, vol. 1, Pasadena, CA, Oct. 25-29, 1993, JPL Pub. 93-28, NASA/JPL, pp. 205-8.

[11] C. A. Wessman, "Remote Sensing and the Estimation of Ecosystem Parameters and Functions," in Imaging Spectrometry—a Tool for Environmental Observations, J. Hill and J. Megier, Eds. Dordrecht, The Netherlands: Kluwer, 1994b, pp. 39-55.

[12] R. O. Green and D. A. Roberts, "Vegetation species composition and canopy architecture information expressed in leaf water absorption measured in the $1000 \mathrm{~nm}$ and $2500 \mathrm{~nm}$ spectral region by an imaging spectrometer," in Summaries 5th Annu. JPL Airborne Geoscience Workshop, AVIRIS Workshop, vol. 1, Pasadena, CA, Jan. 23-26, 1995, JPL Pub. 95-1, NASA/JPL, pp. 95-98.

[13] R. W. Thomas and S. L. Ustin, "Discriminating semiarid vegetation using airborne imaging spectrometer data: a preliminary assessment," Remote Sens. Environ., vol. 23, pp. 273-90, 1987.

[14] D. A. Roberts, M. O. Smith, and J. B. Adams, "Green vegetation, nonphotosynthetic vegetation, and soils in AVIRIS data," Remote Sens. Environ., vol. 44, pp. 255-69, 1993.
[15] M. E. Martin, S. D. Newman, J. D. Aber, and R. G. Congalton, "Determining forest species composition using high spectral resolution remote sensing data," Remote Sens. Environ., vol. 65, pp. 249-254, 1998.

[16] D. A. Roberts, R. O. Green, and J. B. Adams, "Temporal and spatial patterns in vegetation and atmospheric properties from AVIRIS," Remote Sens. Environ., vol. 62, pp. 223-240, 1997.

[17] D. A. Roberts, M. Gardner, R. Church, S. Ustin, and G. Scheer, "Mapping chaparral in the Santa Monica Mountains using multiple endmember spectral mixture models," Remote Sens. Environ., vol. 65, pp. 267-279, 1998

[18] G. S. Okin, W. J. Okin, D. A. Roberts, and B. Murray, "Multiple endmember spectral mixture analysis: application to an arid/semi-arid landscape," in Summaries 7th Annu. JPL Airborne Geoscience Workshop, AVIRIS Workshop, Pasadena, CA, Jan. 12-16, 1998, http://makalu.jpl.nasa.gov/docs/workshop/98 docs/toc.html.

[19] M. M. Lewis, "Discrimination of arid vegetation composition with high resolution CASI imagery," Rangeland J., vol. 22, pp. 141-167, 2000.

[20] M. O. Smith, J. B. Adams, and D. E. Sabol, "Spectral Mixture Analysis-New Strategies for the Analysis of Multispectral Data," in Imaging Spectrometry - a Tool for Environmental Observations, J. Hill and J. Megier, Eds. Dordrecht, The Netherlands: Kluwer, 1994, pp. $125-143$.

[21] M. O. Smith, S. L. Ustin, J. B. Adams, and A. R. Gillespie, "Vegetation in deserts: I A regional measure of abundance from multispectral images," Remote Sens. Environ., vol. 31, pp. 1-26, 1990.

[22] P. N. Bierwirth, "Mineral and vegetation mapping over mound spring deposits near Lake Eyre: an application of data-calibrated pixel unmixing using Landsat TM data," in Proc. 5th Australasian Remote Sensing Conf., vol. 1, Perth, Western Australia, Australia, Oct. 8-12, 1990, pp. 341-51.

[23] D. L. Evans and M. O. Smith, "Separation of vegetation and rock signatures in Thematic Mapper and Polarimetric SAR images," Remote Sens. Environ., vol. 37, pp. 63-75, 1991.

[24] M. Fitzgerald and S. L. Ustin, "Measuring dry plant residues in grasslands: A case study using AVIRIS," in Summaries 3rd Annи. JPL Airborne Geoscience Workshop, AVIRIS Workshop, vol. 1, Pasadena, CA, June 1-5, 1992, JPL Pub. 92-14, NASA.JPL, pp. 91-93.

[25] J. A. Gamon, C. B. Field, and S. L. Ustin, "Evaluation of spatial productivity patterns in an annual grassland during an AVIRIS overflight," in Summaries 3rd Annu. JPL Airborne Geoscience Workshop, AVIRIS Workshop, vol. 1, Pasadena, CA, June 1-5, 1992, JPL Pub. 92-14, NASA.JPL, pp. 17-19.

[26] Q. J. Hart, S. L. Ustin, L. Duan, and G. Scheer, "Estimating dry grass residues using landscape integration analysis," in Summaries 4th Annu. JPL Airborne Geoscience Workshop, AVIRIS Workshop, vol. 1, Pasadena, CA, Oct. 25-29, 1993, JPL Pub. 93-28 NASA/JPl, pp. 89-92.

[27] J. F. Mustard, "Relationships of soil, grass, and bedrock over the Kaweah serpentine melange through spectral mixture analysis of AVIRIS data," Remote Sens. Environ., vol. 44, pp. 293-308, 1993.

[28] J. Kupiec, G. M. Smith, and P. J. Curran, "AVIRIS spectra correlated with the chlorophyll concentration of a forest canopy," in Summaries 4th Annu. JPL Airborne Geoscience Workshop, AVIRIS Workshop, vol. 1, Pasadena, CA, Oct. 25-29, 1993, NASA/JPL, JPL Pub. 93-28, pp. $105-8$.

[29] A. A. Held and D. L. B. Jupp, "Use of the Compact Airborne Spectral Imager (CASI) for remote sensing of vegetation function and dynamics," in Proc. 7th Australasian Remote Sensing Conf., vol. 2, Melbourne, Australia, Mar. 1-4, 1994, pp. 573-80.

[30] R. N. Clark, T. King, C. Ager, and G. A. Swayze, "Initial vegetation species and senescence/stress indicator mapping in the San Luis Valley, Colorado using imaging spectrometer data," in Summaries 5th Annu. JPL Airborne Geoscience Workshop, AVIRIS Workshop, Pasadena, CA, Jan. 23-26, 1995, JPL Pub.98-1, NSA/JPL, pp. 35-38.

[31] T. P. Dawson and P. J. Curran, "A new technique for interpolating the reflectance red edge position," Int. J. Remote Sensing, vol. 19, pp. 2133-2139, 1998.

[32] R. Merton, "Monitoring community hysteresis using spectral shift analysis and the red-edge vegetation stress index," in Summaries 7th Annu. JPL Airborne Geoscience Workshop, AVIRIS Workshop, Pasadena, CA, Jan. 12-16, 1998, http://makalu.jpl.nasa.gov/docs/workshops/98_docs/toc.html.

[33] C. D. Elvidge and F. P. Portigal, "Reflectance spectra of green and dry vegetation derived from 1989 AVIRIS data," in Proc. 5th Australasian Remote Sensing Conf., vol. 1, Perth, WA, Australia, Oct. 8-12, 1990, pp. $185-95$.

[34] E. M. Rollin and E. M. Milton, "Processing of high spectral resolution reflectance data for the retrieval of canopy water content information," Remote Sens. Environ., vol. 65, pp. 86-92, 1998. 
[35] E. W. Sanderson, M. Zhang, S. L. Ustin, and E. Rejmankova, "Geostatistical scaling of canopy water content in a California salt marsh," Landscape Ecol., vol. 13, pp. 79-92, 1998.

[36] D. L. Peterson, J. D. Aber, P. A. Matson, D. H. Card, N. Swanberg, C. Wessman, and M. Spanner, "Remote sensing of forest canopy and leaf biochemical contents," Remote Sens. Environ., vol. 24, pp. 85-108, 1988.

[37] C. D. Elvidge, "Visible and near infrared reflectance characteristics of dry plant materials," Int. J. Remote Sensing, vol. 11, pp. 1775-95, 1990.

[38] P. Curran, "Remote sensing of foliar chemistry," Remote Sens. Environ., vol. 30, pp. 271-78, 1989.

[39] A. A. Green and M. D. Craig, "Analysis of aircraft spectrometer data with logarithmic residuals," in Proc. Airborne Imaging Spectrometer Workshop, Pasadena, CA, 1985, JPL Pub. 85-41, pp. 111-119.

[40] M. E. Winter, "Fast Autonomous Spectral endmember Determination in Hyperspectral Data," in Proc. 13th Int. Conf. Applied Geologic Remote Sensing, vol. II, Vancouver, BC, Canada, 1999, pp. 337-344.

[41] R. D. Graetz, R. P. Pech, and A. W. Davis, "The assessment and monitoring of sparsely vegetated rangelands using calibrated Landsat data," Int. J. Remote Sensing, vol. 9, pp. 1201-1222, 1988.

[42] G. N. Bastin, G. Pickup, V. H. Chewings, and G. Pearce, "Land degradation assessment in central Australia using a grazing gradient method," Rangeland J., vol. 15, pp. 190-216, 1993.

[43] C. A. Wessman, J. D. Aber, D. L. Peterson, and J. M. Mellilo, "Remote sensing of canopy chemistry and nitrogen cycling in temperate forest ecosystems," Nature, vol. 335, pp. 154-156, 1988.

[44] C. A. Wessman, C. A. Bateson, and T. L. Benning, "Detecting fire and grazing patterns in tallgrass prairie using spectral mixture analysis," Ecol. Applicat., vol. 7, pp. 493-511, 1997.

[45] D. S. Himmelsbach, H. Boer, D. E. Akin, and F. E. Barton, "SolidState Carbon-13 NMR, FTIR and NIRS Spectroscopic Studies of Ruminant Silage Digestion," in Anal. Applicat. Spectrosc., C. Creaser and A. Davies, Eds. Cambridge, U.K.: R. Soc. Chem., 1988, pp. 410-413.

[46] B. Osborne, "Determination of Fat in a Variety of Cereal Foods using NIR Spectroscopy," in Analytical Applications of Spectroscopy, C. Creaser and A. Davies, Eds. Cambridge, U.K.: R. Soc. Chem., 1988, pp. $68-71$

[47] D. Bertrand, P. Roberts, M. F. Devaux, and J. Abecassis, “Assignment of Near Infrared Absorption Bands by Multidimensional Analyzes of Special Data: Application of the Estimation of Purity in Durum Wheat Products," in Analytical Applications of Spectroscopy, C. Creaser and A. Davies, Eds. Cambridge, U.K.: R. Soc. Chem., 1988, pp. 450-456.

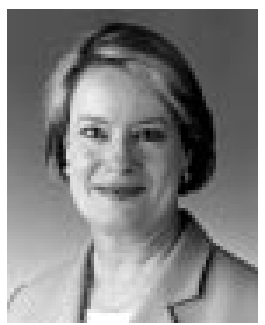

Megan Lewis received the M.S. degree in environmental studies from Adelaide University, Adelaide, Australia, and the M.S. and Ph.D. degrees in remote sensing from the University of New South Wales, New South Wales, Australia.

She has lectured in ecology at the South Australian College of the Arts and Education, Adelaide, Australia, and later in natural resource management at Roseworthy Agricultural College, South Australia, Australia, where she was Head of the Department of Land Resources Management from 1984 to 1989. She has been a Senior Lecturer with Adelaide University, Adelaide, Australia, since 1991, specializing in remote sensing and vegetation ecology and leading the Spatial Information Research Group within the Department of Soil and Water. In addition to lecturing, she has served as an Environmental Specialist on several Australian state and commonwealth advisory committees and statutory bodies.

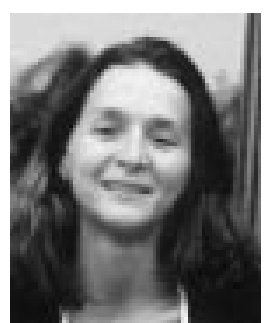

Vittoria Jooste received the M.Sc in geology from the University of Florence, Florence, Italy, in 1993 , completing a thesis in remote sensing.

After one year as a GIS consultant with the United Nations FAO, Rome, Italy, she joined Gold Fields of South Africa and then the Anglo American Corporation, Johannesburg, South Africa, where she became involved in the development of an airborne hyperspectral scanner for mineral exploration. She is currently in charge of the Remote Sensing Section, De Beers GeoScience Centre, Johannesburg, where she coordinates hyperspectral, multispectral, and radar remote sensing projects and research activities.

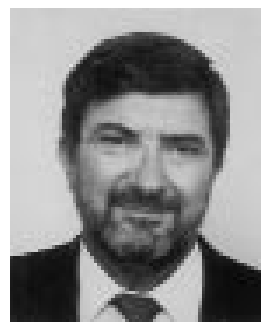

Aurelio A. de Gasparis received the "laurea in Science Geologiche" degree (summa cum laude) from the University of Napoli, Napoli, Italy, completing a thesis on a magnetic survey of Mount Vesuvius, the M.Sc. degree in isotope geology from the Bernard Price Institute, Witwatersrand University, Johannesburg, South Africa, and the Ph.D. degree in earth sciences from Pittsburgh University, Pittsburgh, PA.

After working as a Research Assistant and a Field Geologist in South Africa, he then emigrated to the U.S. After a Postdoctoral Fellowship with the NASA Goddard Space Flight Center, Greenbelt, MD, where he worked on crops spectral response, he joined Gulf Research and Technology Company. In 1981, he joined the Anglo-American Corporation of South Africa Limited, Johannesburg, as Head of the Remote Sensing Section. After retiring from this position, became Director at HyVista Corporation, Norwood, South Africa, a company that offers airborne hyperspectral services. 